\title{
First Report of Stilt Crab Crossotonotus spinipes (Decapoda: Palicoidea: Crossotonotidae) from Korea
}

\author{
Sang-kyu Lee ${ }^{1}$, Sa Heung $\mathrm{Kim}^{2}$ and Won Kim ${ }^{1, *}$ \\ ${ }^{1}$ School of Biological Sciences, Seoul National University, Seoul 151-746, Korea \\ ${ }^{2}$ Laboratory of Marine Biodiversity, IN THE SEA KOREA Co. Ltd., Seogwipo 697-110, Korea
}

\begin{abstract}
A stilt crab Crossotonotus spinipes (De Man, 1888) is newly reported from Korean waters as a result of continuous taxonomic studies on crabs. The present specimen has a row of tubercles and a longitudinal lobe with denticles on the dorsal border of the propodus of the chelipeds, and a shorter Pereopod 5. The description and illustration of this species are provided.
\end{abstract}

Keywords: first report, Crossotonotus spinipes, Crossotonotidae, Decapoda, Korean fauna

\section{INTRODUCTION}

Crossotonotus spinipes (De Man, 1888), a member of the superfamily Palicoidea, can be found in a variety of habitats from coral reefs of shallow water to deep sea. This species shows very wide distribution throughout the Indo-West Pacific region. However, it is rarely captured in large numbers and almost nothing is known of their biology or life histories (Davie, 2002). The genus Crossotonotus A. Milne Edwards, 1873 including this species consists of four species worldwide: Crossotonotus ceramensis (Moosa and Serène, 1981), C. compressipes A. Milne-Edwards, 1873, C. lophocheir Castro, 2000, and C. spinipes (De Man, 1888) (Ng et al., 2008). Continuous taxonomic study on crabs collected from Korean waters revealed that $C$. spinipes is new to the Korean fauna. The present specimen is described with an illustration in this paper.

The specimen was collected from an underwater cave in Jejudo Island by SCUBA diving. It was preserved in $70 \%$ ethyl alcohol. All drawings were prepared using camera lucida on a Leica MZ8. The abbreviations "cl" and "cw" refer to the carapace length and width, respectively. The length of the carapace was measured across the middle of the carapace from the tip of the longest lobe of the frontal border to the posterior border, including any tubercles along the posterior border. The width of the carapace was measured across the widest breadth, including the longest anterolateral tooth on each side. The material in present study is deposited in the Marine Arthropod Depository Bank of Korea (MADBK), Seoul National University.

*To whom correspondence should be addressed

Tel: 82-2-880-6695, Fax: 82-2-872-1993

E-mail:wonkim@plaza.snu.ac.kr

\section{SYSTEMATIC ACCOUNTS}

$1 *$ Superfamily Palicoidea Bouvier, 1898

2*Family Crossotonotidae Moosa and Serène, 1981

${ }^{3 *}$ Genus Crossotonotus A. Milne-Edwards, 1873

${ }^{4}$ *Crossotonotus spinipes (De Man, 1888) (Fig. 1)

Pleurophricus spinipes De Man, 1888: 344, pl. 15, fig. 1, 1a-c.

Manella spinipes: Ward, 1933: 389.

Manella gardineri Rathbun, 1911: 240, pl. 20, fig. 9; Ward, 1933: 389.

Manella brevimana Ward, 1933: 387, pl. 21, figs. 7, 8; Moosa and Serène, 1981: 54, figs. 12a-b, 13 a.

Crossotonotus spinipes: Castro, 2000: 574, figs. 45, 46, 51, $61 f$.

Material examined. $1 \mathrm{\sigma}^{7}$ (cl $28.9 \mathrm{~mm}$, cw $\left.35.5 \mathrm{~mm}\right)$, underwater cave ‘Geomunnieo', Jujudo Is., 7 Jul. 2003, coll. S.H. Kim.

Description. Carapace (Fig. 1A) subquadrate, depressed, slightly broader than long, with slightly swollen areas with low concaves topped by rounded tubercles; anterolateral border with three broad, pointed teeth (first and second typically bifurcated); lateral border with 3 or 4 large, pointed or blunt tubercles; posterolateral border with 4-6 similar but slightly smaller, pointed tubercles; posterior border with sixteen rounded or pointed tubercles. Front margin with four lobes; tips bent upward, median lobes broader and notched. Orbits deep; supraorbital border with two triangular lobes; suborbital borders with two broad and rectangular lobes bordered by long, narrow teeth. Cornea of eyes spherical, slightly wider than base of eye peduncle. Peduncle of eyes with granular tubercles at least on distal border. Each basal

${ }^{1 *}$ 죽마게상과 (신칭), ${ }^{2 *}$ 큰다리죽마게 과 (신칭), ${ }^{3 *}$ 큰다리죽마게 속 (신칭), ${ }^{4 *}$ 털다발죽마게 (신칭) 


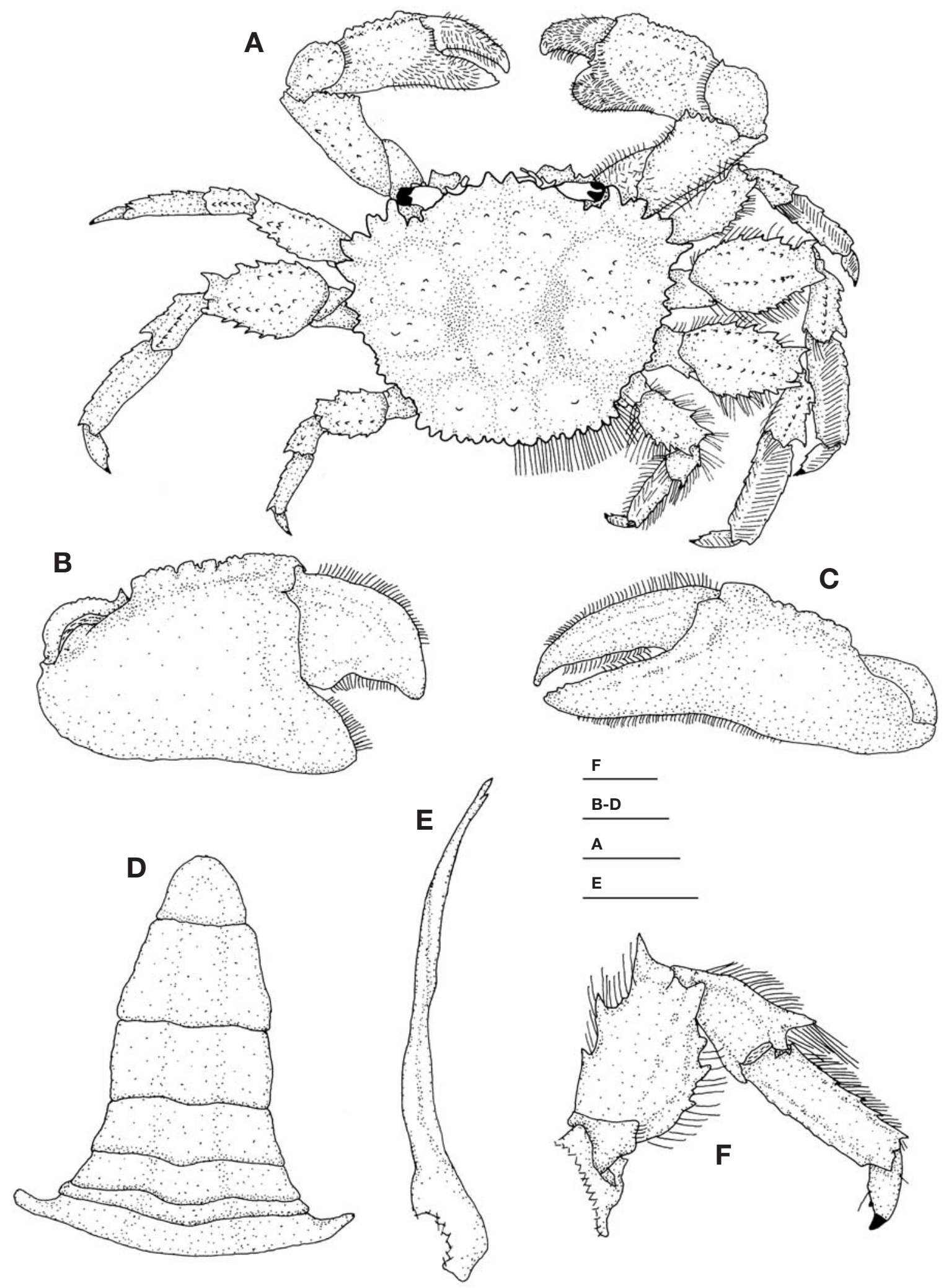

Fig. 1. Crossotonotus spinipes (De Man, 1888), male. A, whole crab, dorsal view; B, right cheliped, outer view; C, left cheliped, outer view; $D$, abdomen, ventral view; $E$, left first pleopod, ventral view; $F$, fifth pereopod, ventral view. Scale bars $=10 \mathrm{~mm}(A), 5$ $\mathrm{mm}(B-D), 3 \mathrm{~mm}(E, F)$. Note=Setae on the left part of the whole animal are omitted, except those on the palm of the cheliped. 
antennal segment rectangular, with or without small, outward expansion. Epistome very narrow, not expanded dorsoventrally, vertically inclined. Meri of third maxillipeds smaller and narrower than ischia.

Chelipeds of male (Fig. 1B, C) unequal. Dorsal border of propodus with two conspicuous rows: outer row longitudinal lobe with denticles, and inner row small tubercles. Distal inner surface of propodi and proximal border of dactyli of males with cluster of abundant plumose setae. Propodus of major cheliped with lower border expanded form J-shaped proximal edge.

Pereopods (Fig. 1A, F) flattened, with hairs. Second and fifth pairs of pereopod shorter than third and fourth one. Meri with 3-4 spines and seta on anterior and posterior borders; distal terminal with spines; dorsal surface bearing two rows of small spines. Dactyli of second to fourth pereopods with three or four teeth along dorsal and ventral borders. Dactyli of fifth pereopods with 2 spines along posterior borders.

Abdomen of male (Fig. 1D) subtriangular, and smooth, all free segments, consisting of seven segments.

First gonopod of male (Fig. 1E) with sinuous basal parts; each distal part straight, on simple tip bordered by minute teeth.

Remarks. The superfamily Palicoidea Bouvier, 1898 includes the families Palicidae Bouvier, 1898 and Crossotonotidae Moosa and Serène, 1981. While the fifth pairs of pereopods (P5) of the members of the family Palicidae are greatly reduced and slender as the P5 of the dorippid crabs, those of Crossotonotus spinipes (De Man, 1888) belonging to the family Crossotonotidae are identical in shape to the remaining pereopods (P2-P4) (Castro, 2000; Ng et al., 2008).

The propodus of chelipeds of $C$. spinipes has two conspicuous rows of pointed or rounded tubercles on the dorsal borders, and the similar-sized four teeth on the suborbital border. The total length of P2 and P5 is about 1.0 and 0.9 times as that of the carapace, respectively (Rathbun, 1911; Castro, 2000). The present specimen, however, has a row of tubercles and a longitudinal lobe with denticles. The two inner suborbital teeth of this specimen are bigger than the two outer suborbital teeth. The total length of P2 and P5 is about 1.0 and 0.7 times that of the carapace, respectively. The P5 of the present specimen is somewhat shorter than those of $C$. spinipes specimen recorded previously.

Ward (1933) reported three sorts of tomentose patches on the inner surface of chelipeds: (1) the inner surface of the propodus has a small patch of hair distally, (2) the inner surface of that is bare, and (3) the distal inner surface of the pro- podus is tomentose. The chelipeds of the present specimen have tomentosa on the distal inner surface of the propodus.

Habitat. Benthic, intertidal to $146 \mathrm{~m}$ depth coral reef, reef flat, rock bottom, rock reef, rubble bottom.

Colour. Gray coloured carapace and legs. Light spots on each region of carapace.

Distribution. Red sea; Seychelles, Amirante Islands; Indonesia; Queensland, Australia; Southeast Japan; Taiwan; Xisha Island, South China; Palau; Hawaiian Islands; Jejudo Island, Korea (present study).

\section{ACKNOWLEDGEMENTS}

This work was supported by a grant from Marine Biotechnology Programme Funded by Ministry of Land, Transport and a grant (No. 2006-421) from the Ministry of Environment of the Korean Government.

\section{REFERENCES}

Castro, P., 2000. Crustacea Decapoda: A revision of the Indowest pacific species of palicid crabs (Brachyura Palicidae). Mém. Mus. Natn. Hist. nat., Paris, 184: 1-813.

Davie, P.J.F., 2002. Crustacea: Malacostraca: Eucarida (Part 2): Decapoda-Anomura, Brachyura. Vol. 19.3B. In: Zoological Catalogue of Australia (Eds., A. Wells and W.W.K. Houston). pp. 1-641. CSIRO Publiching, Melbourne.

De Man, J.G., 1888. Bericht über die von Herrn Dr. J. Brock im indischen Archipel gesammelten Decapoden und Stomatopoden. Arch. Naturgesch, 53(1): 215-600.

Moosa, M.K. and R. Serène, 1981. Observations on the IndoWest-Pacific Palicidae (Crustacea: Decapoda) with description of two new subfamilies, four new genera and six new species. Mar. Res. Indonesia, 22: 21-66.

Ng, P.K.L., D. Guinot and P.J.F. Davie, 2008. Systema Brachyurorum: Part 1. An annotated checklist of extant brachyran crabs of the world. Raff. Bull. Zool., 17: 2-286.

Rathbun, M.J., 1911. Marine Brachyura. The Percy Sladen Trust Expedition to the Indian Ocean in 1905, under the leadership of Mr. J. Stanley Gardiner, Vol. 3, no. 11. Transactions of the Linnean Society, London, Ser. 2, 14(2): 191261.

Ward, M., 1933. New genera and species of marine Decapoda Brachyura from the coasts of New South Wales and Queensland. Aust. Zool., 7(5): 377-394. 